\title{
Review \\ GLP-1 Receptor Agonists in Diabetic Kidney Disease: From Physiology to Clinical Outcomes
}

\author{
Alba Rojano Toimil ${ }^{1}$ and Andreea Ciudin 1,2,3,*(D) \\ 1 Endocrinology and Nutrition Department, Hospital Universitari Vall Hebron, 08035 Barcelona, Spain; \\ arojano@vhebron.net \\ 2 Institut de Recerca Vall d'Hebron, Universitat Autònoma de Barcelona (VHIR-UAB), 08916 Barcelona, Spain \\ 3 CIBER de Diabetes y Enfermedades Metabólicas Asociadas, Instituto de Salud Carlos III, 28029 Madrid, Spain \\ * Correspondence: aciudin@vhebron.net; Tel.: +34-9327-46591
}

Citation: Rojano Toimil, A.; Ciudin, A. GLP-1 Receptor Agonists in Diabetic Kidney Disease: From Physiology to Clinical Outcomes. J. Clin. Med. 2021, 10, 3955. https:// doi.org/10.3390/jcm10173955

Academic Editor: Tatsuo Shimosawa

Received: 15 July 2021

Accepted: 31 August 2021

Published: 31 August 2021

Publisher's Note: MDPI stays neutral with regard to jurisdictional claims in published maps and institutional affiliations.

Copyright: (c) 2021 by the authors. Licensee MDPI, Basel, Switzerland. This article is an open access article distributed under the terms and conditions of the Creative Commons Attribution (CC BY) license (https:/ / creativecommons.org/licenses/by/ $4.0 /)$.

\begin{abstract}
Diabetic kidney disease (DKD) is one of the most common complications in type 2 diabetes mellitus (T2D) and a major cause of morbidity and mortality in diabetes. Despite the widespread use of nephroprotective treatment of T2D, the incidence of DKD is increasing, and it is expected to become the fifth cause of death worldwide within 20 years. Previous studies have demonstrated that GLP-1 receptor agonists (GLP-1 RA) have improved macrovascular and microvascular outcomes independent of glycemic differences, including DKD. GLP-1Ras' improvement on kidney physiology is mediated by natriuresis, reduction in hyperfiltration and renin-angiotensin-aldosterone system (RAAS) activity and anti-inflammatory properties. These findings translate into improved clinical outcomes such as an enhanced urine albumin-to-creatinine ratio (UACR) and a reduction in renal impairment and the need for renal replacement therapies (RRT). In this article, we review the role of GLP-1RAs on the mechanisms and effect in DKD and their clinical efficacy.
\end{abstract}

Keywords: diabetic kidney disease; GLP-1 receptor agonists; diabetic kidney disease

\section{Introduction}

In the past 20 years, the management of type 2 diabetes (T2D) and its complications has improved substantially. Control of cardiovascular risk factors, such as dyslipidemia, obesity, smoking and changes in other modifiable factors based on strict blood pressure control, use of RAAS inhibitors and adequate glycemic treatment, has resulted in improvement in the incidence in T2D related myocardial infarction, stroke, amputations and mortality [1-3]. However, diabetic kidney disease (DKD) remains the leading cause of chronic kidney disease (CKD), kidney failure (KF) and need for renal transplantation (RT) [4,5]. A study performed in a primary care setting showed that $27.9 \%$ of patients with T2D presented some degree of $C K D$, and the prevalence of patients with a urinary albumin to creatinine ratio (UACR) $\geq 30 \mathrm{mg} / \mathrm{g}$ was $15.4 \%$ [6]. In the KDIGO study, the percentage of T2D patients with CKD defined as either a glomerular filtration rate (GFR) below $60 \mathrm{~mL} / \mathrm{min} / 1.73 \mathrm{~m}^{2}$ or UACR $\geq 30 \mathrm{mg} / \mathrm{g}$ was $43.1 \%$ in those patients aged $\geq 65$ years [7]. All this evidence further shows the importance of optimizing DKD management.

Current standards of diabetes care recommend metformin as initial therapy, after life style modification in patients with T2D. Recently, the guidelines have included in the algorithm for choosing the second line of treatment the criteria of an increased cardiovascular risk, cardiovascular disease or renal complications [8]. In the past decade, two new classes of antihyperglycemics drugs have been introduced in the clinical practice (sodium-glucose cotransporter-2 inhibitors-SGLT2 and GLP1-receptor agonists-GLP-1RAs) that showed a significant decrease in cardiovascular risk and the progression of DKD [9]. At present, there is significant data regarding the role of SGLT-2 inhibitors on DKD (clinical outcomes and mechanisms) $[10,11]$. Nevertheless, the role of GLP-1-RAs was not so well represented, despite the significant results from different studies. 
The GLP1RAs are included in the incretin-based therapies as well as dipeptidyl peptidase 4 (DPP-4) inhibitors. GLP1 is a peptide secreted during ingestion and its mean effect is reflected on glucose metabolism by insulinotropic signals mediated by GLP1 receptors, which are highly expressed on B-pancreatic cells [12]. This hormone potentiates the insulin secretion and contributes to glucose homeostasis through a wide range of physiological actions not only on pancreatic cells but also in other systems, such as the central nervous system (CNS) through the regulation of homeostatic feeding and the gastrointestinal tract by slowing gastric emptying [13,14]. The main limitation of the native GLP-1 is the short half-life (3-5 $\mathrm{min}$ ) due to rapid degradation by the DPP-IV enzyme.

The first drug from the GLP-1RAs' class was exenatide, which was approved by the US Food and Drug Administration (FDA) in April 2005 for the treatment of T2D. It consists in a 39-aminoacid peptide made by a substitution of an Ala8Gly of the exendin4 hormone found in the saliva of the Gila monster. This modified chemical structure confers resistance to the degradation of DPP-4 [15]. From that moment, several GLP-1 peptides were modified to confer resistance to DPPIV, limit renal clearance and delay subcutaneous tissue absorption and therefore increase half-life. On these bases, we can classify GLP1-RAs in short-acting or prandial, such as exenatide and liraglutide, with a duration up to 2-4 h, and long acting GLP1-RAs, that have half-lives of up to a week such as albiglutide, dulaglutide and semaglutide $[14,16]$. Diverse effects in terms of improved weight loss $[17,18]$ and a reduction in glycated hemoglobin (HbA1c) [19] have been demonstrated.

The lack of trials in DKD has limited the experience of pharmacokinetic and clinical data with GLP-1AR in these group of patients with T2D. Therefore, caution or discontinuation was recommended when renal function is severely impaired [20]. However, in recent trials with GLP1-Ras' liraglutide and semaglutide that included patients with a GFR up to $15 \mathrm{~mL} / \mathrm{min} / 1.73 \mathrm{~m}^{2}$, post-hoc analysis demonstrated the safety in patients with CKD [21-23], underlying a potential renal protection with this class of drugs.

In this review, we focus on the role of GLP-1 (and GLP-1-RAs) in the physiology of the gut-renal axis, the renoprotective mechanisms of this incretin therapies and the renal outcomes obtained in the most recognized clinical studies using GLP1-RAs in patients with T2D.

\section{The Association of GLP-1 and Gut-Renal Axis}

As mentioned above, GLP-1 and GIP are two incretin hormones responsible for the reduction in blood glucose levels in response to nutrient ingestion. In fact, humans submitted to an oral glucose load showed a much greater increase in plasma insulin levels than those infused with intravenous glucose administration [12]. This phenomenon is known as the incretin effect, and it is estimated to account for approximately $50-70 \%$ of the overall insulin secretory response after nutrient ingestion [24].

Nevertheless, not only a gut-pancreas connection has been demonstrated but also a contribution to the physiological control of water and electrolyte balance upon meal ingestion. The regulation of the gut-renal axis is mediated by multiple pleiotropic actions in different locations such as the central nervous system, adjusting thirst, intestinal cotransporters to control fluid and electrolyte absorption and secretion and also on the kidney, by the stimulation of renal tubular excretion and/or reabsorption of fluid and electrolytes [25,26]. As the effect previously exposed with oral glucose administration, GLP1 release by oral sodium load can stimulate more rapidly the tubular excretion by the kidney than given intravenously, independent of changes in the levels of aldosterone and atrial natriuretic peptide on plasma $[27,28]$. The same changes have been observed on potassium and phosphate metabolism [29].

The role of GLP1 is not only limited on tubular effects but also on changes on hemodynamics. For example, a postprandial hyperfiltration induced after ingestion of a high protein meal by an increase in renal blood flow was identified. This mechanism contributes in part of sodium and solutes homeostasis after ingestion by increasing the pressure and 
vasodilation of the afferent arteriole through nitric oxide [30]. From a pathophysiological point of view, an impaired gut-renal axis implies a reduction in urinary secretion and, therefore, a salt-sensitive hypertension. The glomerular hyperfiltration classically has been related to T2D and the CKD progression. Nevertheless, the postprandial hyperfiltration induced by GLP1 is minimal and has no clinical impact [31].

\section{Renoprotective Mechanisms of GLP1-RAs in T2D}

There are several experimental studies that evaluate the effects of GLP1 and GLP1-RAs on the renal metabolism and shed light on the main mechanisms responsible for changes in eGFR, a reduction in albuminuria and other renal outcomes seen in clinical studies. In this section, we will explain in detail the main mechanisms underlying the attenuation of DKD by GLP1-RAs.

\subsection{Glucose Lowering}

The main renoprotective effect of incretin-based therapies such GLP1-RAs is mediated by regulation of the glucose metabolism. Indeed, the most known effect of the GLP1 gut derived hormone is the reduction in hyperglycemia in T2D which is severely impaired or lost on those patients [32,33]. Its mechanism is based on increasing the insulin secretion and synthesis in pancreatic islet cells and a decrease in glucagon secretion and $\beta$-cell apoptosis [34,35]. In fact, it has been published that GLP-1RAs reduce $\mathrm{HbA}_{1 \mathrm{c}}$ levels by $\sim 1.0 \%$ compared with a placebo [19]. Other actions that contribute to glucose homeostasis include the diminution of gastric emptying and small intestine peristalsis and suppression of endogenous glucose production [36,37]. Another fact that supports this proposition is that the reduction in new-onset albuminuria in clinical studies with GLP-1RA is accompanied by effective glucose lowering [38].

\subsection{Oxidative Stress and Inflammation}

Various reports have shown that T2D is associated with chronic low-grade inflammation, which is linked with oxidative stress, proliferation and fibrosis that affect kidney function and morphology [39]. Experimental studies have reported that GLP1-RAs inhibit inflammatory signaling pathways of DKD, such as nicotinamide adenine dinucleotide phosphate (NADPH) oxidase by activating protein kinase A (PKA) and the production of cyclic adenosine monophosphate (cAMP), which is paralleled by reductions in albuminuria and improved histological features of DKD [40]. For example, exendin-4 was shown to inhibit proliferation and fibrosis in human mesangial cells by stimulation of cAMP and PKA [41].

Another main molecular target implicated in oxidative stress and progression to DKD is the nuclear factor kappa-light-chain-enhancer of activated B cells (NF-kB). The activation of this pro-inflammatory protein complex is induced by hyperglycemia and attenuates the therapeutic effects of the GLP-1R agonist by its downregulation [42]. The beneficial effects of GLP1-R signaling might also be mediated by increasing eNOS endothelial levels and inhibiting the expression of TNF-alfa in podocytes, both mediated by NF-kB downregulation [32,43]. Similarly, liraglutide has been shown to reduce the structural damage of podocytes in a model of glomerulopathy related to obesity [32]. Additionally, in rodent models treated with liraglutide, this GLP-1RA also modulates other pathways involved DKD, such as JAK/STAT and MAPK pathways present in kidney endothelial cells in rat CKD models $[19,33]$.

\subsection{Natriuresis-Tubular Effect}

GLP-1 has been previously demonstrated to induce renal sodium excretion and increase urine flow in experimental and clinical studies in healthy and T2D individuals [44-46]. This effect is carried out by GLP1-RA inhibition of sodium-hydrogen exchanger 3 (NHE3), a channel localized in the apical membrane of the epithelial cells of the proximal tubule on the nephron. This process is mediated by PKA activation through cAMP generation and, finally, 
NHE3 phosphorylation [47,48]. Additionally, GLP-1RA has an indirect effect also, by influencing the RAAS by reducing renin and angiotensin II circulating levels and action. [49,50]. Furthermore, GLP1-RAs were described to play a role in natriuresis and diuresis, by modulating the tubular ionic exchange of potassium, chloride and calcium $[49,51,52]$.

\subsection{Endothelial Function-Glomerular Effect}

It is well known that the mechanism of hyperfiltration is a prime disruptor in DKD, especially when it is accompanied by albuminuria and renal function decline, which is observed in advance stages of the disease [53]. The GLP1-RAs' effect on glomerular hemodynamics is still controversial and remains to be elucidated.

In rodent models, GLP1-RA mediated the increase in endothelial nitric oxide synthase (eNOS) activity and expression, and nitric oxide (NO) production was described. This $\mathrm{NO}$ increase produces a direct vasodilation effect mainly on preglomerular arterioles that increases the glomerular filtration rate (GFR) [54,55]. Additionally, the increase in GFR and effective renal plasma flow (ERPF) induced by NO-dependent glomerular afferent arteriole vasodilation has been reported in numerous preclinical studies during short-term interventions with GLP-1 and GLP-1RAs [50,56,57]. It should be mentioned that all these models have been performed in rodents without diabetes, and the dose administration of GLP-1 and GLP1-RAs exceeds human therapeutic concentrations. In humans, it has been reported in one clinical study that exenatide infusion in ten healthy overweight men increased inulin-measured GFR and ERPF [58].

On the other hand, other clinical and animal studies suggest that GLP1-RAs' therapies reduce glomerular hyperfiltration and provide renoprotection in DKD. In experimental studies in diabetic rodents, $4-8$ weeks of administration of liraglutide and linagliptin significantly reduced glomerular hyperfiltration [59]. In clinical studies, it has been observed that single dose GLP-1 infusion reduced GFR measurements in 16 subjects with obesity that presented hyperfiltration [37]. Additionally, liraglutide produced a decrease in GFR and albuminuria in patients with T2D and normal filtration [59].

These discrepancies on GLP1-RAs' effects on renal hemodynamics may be explained by differences in the characteristics of the studied population, the dose administrated and the posology or differences in study designs.

\subsection{Blood Pressure}

GLP1RAs treatment points to a clinically relevant lowering effect on blood pressure. These results can be partially explained by indirect effects on weight loss, an increase in natriuresis and the regulation of RAAS [60-62]. Moreover, independent effects on NO dependent vasorelaxation as well as changes in endothelial cell function could be involved. A single-blind randomized crossover study on 12 patients with T2D with stable coronary artery disease that underwent intravenous infusion of human recombinant GLP-1 described a significant increase in the brachial artery diameter. This effect was proven to be mediated by the GLP-1 via expression of the GLP1-receptor in endothelial cells (western blotting of cell lysates) [63]. Similar effects have been observed in the femoral artery after exendin infusion in rats [64]. In a meta-analysis of 60 randomized control trials, blood pressure was only significantly reduced with liraglutide and albiglutide compared with a placebo; a non-statistical effect was observed with exenatide and dulaglutide [61]. Evidence to link blood pressure reduction to GLP-1R signaling and mechanisms is scarce and only partially understood.

\subsection{Dyslipidemia}

GLP1-RAs have a main glucose lowering effect by stimulating $\beta$-cell pancreatic secretion and inhibiting glucagon production. Strict control of dyslipidemia was shown to have a beneficial effect on DKD [62]. This metabolic response implicates changes in the lipid profile resulting in lower levels of triglyceride and low-density lipoproteins, as has been broadly described in literature [65]. Nonetheless, in clinical practice, these changes were 
marginal in GLP-1 therapies compared to a placebo [66], and the role in DKD remains to be elucidated.

\subsection{Body Weight}

Abdominal obesity is related with T2D and the associated chronic complications such as DKD [67]. Several studies have shown that being overweight is an independent risk factor for CKD and an increase in visceral fat plays the main role in its pathogenesis. In fact, it is well known that the mechanism of renal damage in obesity is very similar to T2DM, with initial augmentation in eGFR and intraglomerular pression and microalbuminuria that culminate in proteinuria, nodular glomerulosclerosis and tubulointerstitial injury [68-70].

Other conventional glucose-lowering treatments such as insulin or sulphonylureas increases body weight [71]; however, it is well known that GLP1-RAs' treatment in monotherapy or adding to another conventional treatment can lead to a statistically significant weight loss and reduction in the abdominal perimeter [15]. These findings were reported by some randomized clinical trials [72-74] and meta-analyses [75,76]. It is important to note that the predominant effect of these incretin-based therapies is in the reduction of trunk and visceral fat, rather than in lean tissue mass [15,77].

In fact, semaglutide shines as a weight-loss therapy, reaching a decline of $12.4 \%$ compared with a placebo in 68 weeks $(95 \%$ CI, -13.4 to $-11.5 ; p<0.001)$. This means that, in absolute terms, semaglutide obtained a reduction in $15.3 \mathrm{~kg}$ with respect to the baseline (estimated treatment difference, $-12.7 \mathrm{~kg} ; 95 \% \mathrm{CI},-13.7$ to -11.7 ) [18]. Other GLP1RAs' treatment such as liraglutide or exenatide showed a modest decrease in body weight of $-2.51 \mathrm{~kg}(95 \% \mathrm{CI},-3.33$ to $-1.69 ; p<0.001)$ and $-1.69 \mathrm{~kg}(95 \% \mathrm{CI},-2.09$ to $-1.29 ; p<0.001)$, respectively $[78,79]$.

\section{GLP1-RAs and Renal Outcomes in Clinical Trials}

A literature search was conducted in the following databases for the period through 1 January 2005 to 1 April 2021: Medline, Elsevier, Embase and Scopus. Only randomized, double-blind, placebo-controlled trials published that include renal results as primary or secondary outcomes were considered. Ongoing trials were identified using the US National Institutes Health Clinical Trials Registry (www.clinicaltrials.gov accessed on 25 August 2021). It is important to remark that the data provided about GLP1RAs' effect on the kidney are obtained of studies that were designed to aim cardiovascular events, so renal effects were obtained as secondary outcomes-Table 1 (the reduction in renal outcomes was signaled by " $\downarrow$ ").

Table 1. GLP1-RAs and renal outcomes in main clinical trials.

\begin{tabular}{|c|c|c|c|c|c|c|}
\hline Study & $\mathbf{N}$ & Study Design & $\begin{array}{c}\text { Baseline } \\
\text { Characteristics }\end{array}$ & $\begin{array}{l}\text { Median Follow } \\
\text { Up (years) }\end{array}$ & Renal Outcome Studied & Results \\
\hline $\begin{array}{c}\text { LEADER } \\
\text { NCT01179048 }\end{array}$ & 9340 & DB-RCT & T2D + high CV risk & 3.8 & $\begin{array}{c}\text { New-onset } \\
\text { macroalbuminuria, } \\
\text { doubling of the serum } \\
\text { creatinine level, KF, } \\
\text { renal death }\end{array}$ & $\begin{array}{c}\downarrow \text { Renal outcomes } \\
\text { HR } 0.78(95 \% \text { CI: } \\
0.67-0.92)\end{array}$ \\
\hline $\begin{array}{c}\text { SUSTAIN-6 } \\
\text { NCT01720446 }\end{array}$ & 3297 & DB-RCT & $\begin{array}{c}\text { T2D }+\geq 50 \text { years }+ \\
\text { established } \\
\text { CVD } / C K D \text { stage III-V } \\
\text { T2D }+\geq 60 \text { years }+ \\
\text { CV risk factors }\end{array}$ & 2.1 & $\begin{array}{c}\text { New or worsening of } \\
\text { nephropathy (persistent } \\
\text { macroalbuminuria, } \\
\text { doubling of the serum } \\
\text { creatinine level and CCr }< \\
45 \mathrm{~mL} / \mathrm{min} / 1.73 \mathrm{~m}^{2}, \mathrm{RRT} \text { ) }\end{array}$ & $\begin{array}{c}\downarrow \text { Renal outcomes } \\
\text { HR } 0.64(95 \% \text { CI: } \\
0.46-0.88)\end{array}$ \\
\hline $\begin{array}{c}\text { PIONEER-6 } \\
\text { NCT02692716 }\end{array}$ & 31,283 & DB-RCT & $\begin{array}{l}\text { T2D }+\geq 50 \text { years }+ \\
\text { established CVD/ } \\
\text { CKD stage III-V }\end{array}$ & 1.3 & $\begin{array}{c}\text { Changes in eGFR decline } \\
\text { and rate of renal related } \\
\text { death }\end{array}$ & $\begin{array}{l}\text { No statistical } \\
\text { differences }\end{array}$ \\
\hline
\end{tabular}


Table 1. Cont.

\begin{tabular}{|c|c|c|c|c|c|c|}
\hline Study & $\mathbf{N}$ & $\begin{array}{l}\text { Study } \\
\text { Design }\end{array}$ & $\begin{array}{c}\text { Baseline } \\
\text { Characteristics }\end{array}$ & $\begin{array}{l}\text { Median } \\
\text { Follow Up } \\
\text { (Years) }\end{array}$ & Renal Outcome Studied & Results \\
\hline $\begin{array}{c}\text { LOW } \\
\text { NCT03819153 }\end{array}$ & 3508 & QB-RCT & $\begin{array}{l}\text { T2D + established } \\
\text { CKD stage III-IV }\end{array}$ & 5 & $\begin{array}{l}\text { Time to first occurrence } \\
\text { of persistent eGFR } \\
\text { decline }(\geq 50 \%) \text {, reaching } \\
\text { KF, death from KD or CV, } \\
\text { annual rate of change in } \\
\text { eGFR, change in eGFR, } \\
\text { relative change in UACR }\end{array}$ & \\
\hline $\begin{array}{c}\text { AWARD-7 } \\
\text { NCT01621178 }\end{array}$ & 577 & OL-RCT & $\begin{array}{l}\text { T2D + established } \\
\text { CKD stage III-IV }\end{array}$ & 0.997 & $\begin{array}{l}\text { Changes in eGFR decline } \\
\text { and UACR from baseline }\end{array}$ & $\begin{array}{l}\text { No statistical } \\
\text { differences }\end{array}$ \\
\hline $\begin{array}{c}\text { REWIND } \\
\text { NCT01394952 }\end{array}$ & 9901 & DB-RCT & $\begin{array}{l}\mathrm{T} 2 \mathrm{D}+\text { previous } \mathrm{CV} \\
\text { event } / \mathrm{CV} \\
\text { risk factors }\end{array}$ & 5.4 & $\begin{array}{c}\text { New onset of } \\
\text { macroalbuminuria, } \\
\text { sustained eGFR decline } \\
(\geq 30 \%) \text { or RRT }\end{array}$ & $\begin{array}{c}\downarrow \text { Renal outcomes } \\
\text { HR } 0.85 \text { (95\% CI: } \\
0.77-0.93)\end{array}$ \\
\hline $\begin{array}{c}\text { EXSCEL } \\
\text { NCT01144338 }\end{array}$ & 14,752 & DB-RCT & $\begin{array}{c}\text { T2D (70\% with } \\
\text { previous CV event) }\end{array}$ & 3.2 & $\begin{array}{l}\text { New-onset } \\
\text { macroalbuminuria, } 40 \% \\
\text { eGFR decline, } \mathrm{KF}, \\
\text { renal death }\end{array}$ & $\begin{array}{c}\downarrow \text { Renal outcomes } \\
\text { HR } 0.87 \text { (95\% CI: } \\
0.70-1.07)\end{array}$ \\
\hline $\begin{array}{l}\text { HARMONY } \\
\text { NCT02465515 }\end{array}$ & 9463 & DB-RCT & $\begin{array}{l}\text { T2D }+\geq 40 \text { years }+ \\
\text { established CVD }\end{array}$ & 1.6 & Changes in eGFR decline & $\begin{array}{c}\downarrow \text { Renal outcomes } \\
\text { HR } 0.78 \text { (95\% CI: } \\
0.68-0.90)\end{array}$ \\
\hline $\begin{array}{c}\text { ELIXA } \\
\text { NCT01147250 }\end{array}$ & 6068 & DB-RCT & $\begin{array}{l}\mathrm{T} 2 \mathrm{D}+\text { recent acute } \\
\text { coronary event }\end{array}$ & 2.1 & $\begin{array}{l}\text { Percent change in UACR } \\
\text { and eGFR from baseline }\end{array}$ & $\begin{array}{c}\text { Lower UACR CR } \\
(-21.10 \%,-42.25 \\
\text { to } 0.04 ; p=0.0502 \\
\text { in mAlb); } \\
(-39.18 \%,-68.53 \\
\text { to }-9.84 \\
p=0.0070 \text { on } \\
\text { MAlb) }\end{array}$ \\
\hline
\end{tabular}

\subsection{Renal Outcomes with Liraglutide in the LEADER Trial}

In this study, 9340 participants with T2D and high cardiovascular risk were assigned to liraglutide $1.8 \mathrm{mg}$ subcutaneous injection vs. placebo and were followed 3.84 years. The renal outcomes studied included new-onset persistent macroalbuminuria, persistent doubling of serum creatinine, KF and death due to renal disease. All the renal events were grouped on first statistical analysis, and a reduction in its incidence was observed as HR 0.78 (95\% CI: 0.67-0.92), and the main contribution of this effect was the reduction in new onset macroalbuminuria HR 0.74 (95\% CI 0.60-0.91, $p=0.004)$. No differences in the doubling of the serum creatinine, initiation of RRT or renal death were observed. On post hoc analysis, liraglutide showed a reduction in the risk of major adverse $\mathrm{CV}$ events and all-cause mortality in comparison to a placebo in patients with DCKD $\left(e G F R<60 \mathrm{~mL} / \mathrm{min} / 1.73 \mathrm{~m}^{2}\right.$ and UACR > $30 \mathrm{mg} / \mathrm{g}$ ) [80,81].

\subsection{Renal Outcomes with Semaglutide in the SUSTAIN-6 Trial}

Semaglutide subcutaneous treatment showed a reduction in the incidence of new or worsening nephropathy vs. a placebo in a SUSTAIN-6 trial (HR 0.64 (95\%. CI 0.46-0.88, $p=0.05)$ ); the main effect was driven by new onset macroalbuminuria. Concretely, UACR ratios at the end of treatment with respect to baseline were 0.973 with semaglutide $0.5 \mathrm{mg}$, 0.858 with semaglutide $1.0 \mathrm{mg}$ and 1.302 with the placebo. Other outcomes studied were persistent doubling of the serum creatinine level, creatinine clearance $<45 \mathrm{~mL} / \mathrm{min} / 1.73 \mathrm{~m}^{2}$ and need for RRT. No differences were observed in KF or renal death. The baseline characteristics of the patients were T2D patients with established cardiovascular or chronic 
kidney disease; $25.2 \%$ had an eGFR moderately decreased $\left(30-59 \mathrm{~mL} / \mathrm{min} / 1.73 \mathrm{~m}^{2}\right)$ and $2.9 \%$ severely decreased $\left(<30 \mathrm{~mL} / \mathrm{min} / 1.73 \mathrm{~m}^{2}\right)$, and $12.7 \%$ had macroalbuminuria at screening [19].

SUSTAIN 1-5 and 7 post-hoc analyses showed a 30\% reduction in albuminuria and also a regression to micro- or normoalbuminuria was observed in all degrees of albuminuria. Specifically, there was reduction in UACR ratios of 0.74 (95\% CI 0.64 to 0.85 ) with semaglutide $0.5 \mathrm{mg}$ and 0.68 (95\% CI 0.59 to 0.78 ) for semaglutide $1.0 \mathrm{mg}$ versus placebo. A decrease in eGFR were observed at the start of the study in patients with normal kidney function (and in those with mild kidney impairment with semaglutide $1.0 \mathrm{mg}$ in SUSTAIN 6), but no differences were found at the end of the study between semaglutide and the placebo. No increase in the risk of kidney adverse events with semaglutide was seen [19].

\subsection{Renal Outcomes with Semaglutide in the PIONEER-6 Trial}

The main objective of this trial was the evaluation of cardiovascular safety of oral semaglutide. At baseline, 31283 participants with high cardiovascular risk, $\geq 50$ years of age and a cardiovascular and/or chronic disease established were included. It is important to note that $26.9 \%$ of the patients had an eGFR $<60 \mathrm{~mL} / \mathrm{min} / 1.73 \mathrm{~m}^{2}$. Subjects were followed up for 15.9 months. In the results, no statistical differences were observed in the renal outcomes studied (eGFR decline and renal death). No renal outcomes were analyzed in PIONEER-5, but safety was demonstrated for individuals with a moderate eGFR decrease $\left(30-59 \mathrm{~mL} / \mathrm{min} / 1.73 \mathrm{~m}^{2}\right)[82,83]$.

\subsection{Renal Outcomes with Semaglutide in the FLOW Trial}

The FLOW trial is the first and ongoing study with renal outcome as the primary objective, defined as persistent EGFR decline ( $\geq 50 \%$ from the start point), reaching KF or renal death from CV or kidney disease. The enrollment of 3508 participants is estimated in a randomized, quadruple-blind, placebo-controlled trial that evaluates the effect of semaglutide on the progression of renal disease in patients with CKD and T2D. The inclusion criteria are eGFR $\geq 50 \mathrm{~mL} / \mathrm{min} / 1.73 \mathrm{~m}^{2}$ and $\leq 75 \mathrm{~mL} / \mathrm{min} / 1.73 \mathrm{~m}^{2}$, and the UACR between 300 and $5000 \mathrm{mg} / \mathrm{g}$ or eGFR $\geq 25 \mathrm{~mL} / \mathrm{min} / 1.73 \mathrm{~m}^{2}$ and $\leq 50 \mathrm{~mL} / \mathrm{min} / 1.73 \mathrm{~m}^{2}$ and the UACR between 100 and $5000 \mathrm{mg} / \mathrm{g}$. The dose administrated will be titrated from $0.25 \mathrm{mg}$ to $1 \mathrm{mg}$, and the estimated finish date will be in August 2024 [84].

\subsection{Renal Outcomes with Dulaglutide in the AWARD-7 Trial}

Renal outcomes were assessed in AWARD-7: this study included 577 patients with T2D and moderate-to-severe CKD treated with insulin and the maximum dose of an angiotensin-converting enzyme inhibitor or an angiotensin receptor blocker. The response to once-weekly injectable dulaglutide $1.5 \mathrm{mg}, 0.75 \mathrm{mg}$, versus daily insulin glargine was evaluated. The primary outcome was $\mathrm{HbA} 1 \mathrm{c}$ at 26 weeks. Renal outcomes observed were only secondary objectives, as the estimated glomerular filtration rate (eGFR) and urine albumin-to-creatinine ratio (UACR). The effects of dulaglutide on UACR reduction were not statistically significantly different from that of insulin glargine $(22.5 \%$ (95\% CI -35.1 to $-7.5)$ ) with dulaglutide $1.5 \mathrm{mg}(20.1 \%(95 \% \mathrm{CI}-33.1$ to -4.6$))$ with dulaglutide $0.75 \mathrm{mg}$ (95\% CI 13.0\% (-27.1 to 3.9) with insulin glargine). At 52 weeks, eGFR was higher with dulaglutide $1.5 \mathrm{mg}\left(34.0 \mathrm{~mL} / \mathrm{min} / 1.73 \mathrm{~m}^{2} ; p=0.005 \mathrm{vs}\right.$. insulin glargine $)$ and dulaglutide $0.75 \mathrm{mg}\left(33.8 \mathrm{~mL} / \mathrm{min} / 1.73 \mathrm{~m}^{2} ; p=0.009 \mathrm{vs}\right.$. insulin glargine) than with insulin glargine $\left(31.3 \mathrm{~mL} / \mathrm{min} / 1.73 \mathrm{~m}^{2}\right)$. Dulaglutide treatment was associated with a significantly smaller decline in eGFR compared with insulin glargine over 52 weeks. The association between dulaglutide treatment and reduced eGFR decline was most evident in participants with macroalbuminuria [85].

\subsection{Renal Outcomes with Dulaglutide in the REWIND Trial}

In this multicenter, randomized, double-blind and placebo-controlled trial were included 371 participants with at least 50 years of age, with T2D with CV risk factors or a 
previous CV event. A weekly subcutaneous injection of dulaglutide $(1.5 \mathrm{mg})$ was compared with a placebo. The primary outcome on this study was the composite of the following events: non-fatal myocardial infarction, non-fatal stroke or death from cardiovascular causes (including unknown causes). On a follow-up of 5.4 years, the renal outcome (defined as the junction of new macroalbuminuria, sustained decline in eGFR of $30 \%$ or more and need of RRT) occurred in $17.1 \%$ of participants sorted in the dulaglutide treatment branch and in $19.6 \%$ in the placebo group (HR 0.85, 95\% CI 0.77-0.93; $p=0.0004$ ). New onset macroalbuminuria was the only renal outcome to be statistically significant when studied separately (HR $0.7795 \%$ CI $0.68-0.87 ; p=0.0001$ ); no differences were observed in the sustained decline in eGFR (HRs of $0.89(0.78-1.01 ; p=0.066)$ ) and chronic renal replacement therapy $(0.75(0.39-1.44 ; p=0.39))$ [86].

\subsection{Renal Outcomes with Exenatide in the EXSCEL Trial}

The EXSCEL 2017 trial assessed the cardiovascular safety of exenatide in 14.752 patients of whom $73.1 \%$ had previous cardiovascular disease, and were followed for a median of 3.2 years. The primary outcome composite of the first occurrence of death from cardiovascular causes, nonfatal myocardial infarction or nonfatal stroke occurred in $11.4 \%$ in the exenatide group and in $12.2 \%$ in the placebo group (HR, $0.1 ; 95 \% \mathrm{CI}$, 0.83 to 1.00 ). Exenatide therapy was not associated with significant differences in eGFR decline, RRT or renal death. However, based on the data obtained, macroalbuminuria occurred less in the exenatide group (2.2\%) compared to the placebo (2.5\%) (HR 0.87 (95\% CI: 0.70-1.07)) [87]. In post hoc analysis, exenatide did not show statistical differences in any renal outcome studied; neither creatinine clearance, eGFR decline nor new onset progression of albuminuria were observed [88].

\subsection{Renal Outcomes with Albiglutide in the HARMONY Trial}

In HARMONY, the incidence of major adverse cardiovascular events in patients aged 40 years and older with T2D and CV disease occurred in 338 of 4731 (7\%) patients that received a subcutaneous injection of albiglutide and in 428 (9\%) of 4732 patients in the placebo group (hazard ratio $0.78,95 \%$ CI $0.68-0.90$ ). They only examined decline in the estimated glomerular filtration rate as a parameter of kidney outcome, and there were not significant differences in the treatment group versus the placebo. No other renal outcomes were studies [89].

\subsection{Renal Outcomes with Lixisenatide in the ELIXA Trial}

Patients with T2D and a recent acute coronary event (myocardial infarction or unstable angina) were analyzed. This included 6068 patients in a double-blinded placebo-controlled randomized to assess differences in the incidence of cardiovascular death, myocardial infarction, stroke or hospitalization for an unstable angina in individuals treated with a once-daily subcutaneous injection of lixisenatide versus a placebo. In the baseline characteristics, there was a preexisting eGFR decline $\left(<60 \mathrm{~mL} / \mathrm{min} / 1.73 \mathrm{~m}^{2}\right)$ in $25 \%$ of the participants included in the lixisenatide group and $22 \%$ treated with the placebo. In ELIXA, a prespecified analysis of the percentage change in UACR from baseline was employed, and showed a modest difference over the placebo ( $24 \%$ vs. $34 \%, p=0.004)$ [70]. In a post hoc model, changes in the eGFR rate and the UACR adjusted at baseline for albuminuria status were assessed. No statistically significant differences were seen in eGFR decline for lixisenatide treatment versus the placebo overall or adjusted at baseline for albuminuria status. However, in this analysis was obtained a decrease of risk in the first macroalbuminuria event in patients without macroalbuminuria at the start point (HR 0.77; 95\% CI: $0.62,0.96 ; p=0.0174$ ) and a lower UACR change rate in patients treated with lixisenatide with micro- $(-21.10 \%,-42.25$ to $0.04 ; p=0.0502)$ or macroalbuminuria $(-39.18 \%,-68.53$ to $-9.84, p=0.0070)$. All these results were adjusted to HbA1c changes, demonstrating a reduced UACR progression beyond glycemic control [90]. 


\section{Conclusions and New Perspectives}

DKD remains the leading cause of chronic kidney disease, kidney failure and need for RRT $[4,5]$. The classical treatment of this diabetic complication was the control of cardiovascular risk factors and optimization of blood pressure and glycemia [1,2]. However, new treatments are emerging, and GLP1-RAs seem to be an optimal option in patients with T2D and CVD. This hypothesis has been demonstrated by multiple clinical trials based on large cohorts of populations [80-89]. However, renal outcomes always were analyzed as secondary outcomes.

There exists several pre-clinical studies tested on animals that demonstrate the beneficial effects of GLP1-RAs on kidney function. In fact, there is evidence of a direct GLP-1 effect on glomerular homeostasis and tubular ion excretion, mechanisms implicated on hyperfiltration and the main histopathological cause of DKD [45,49,51]. Other effects such as endothelial protection mediated by the inhibition of inflammatory pathways as NAPDH oxidase have been objectivized [40,41]. All these mechanisms were independent of glucose lowering achieving.

Due to the evidence previously exposed, the development of new large clinical trials in the T2D population with DKD is urgently needed to analyze the main effect of GLP1-RAs on the kidney as primary objectives. In fact, there are currently ongoing several clinical trials with GLP1-RA with renal outcomes as the main hypothesis: the effect of liraglutide, lixisenatide and semaglutide on renal complications, such as eGFR decrease or albuminuria progression, is being further studied (NCT01847313, NCT02276196, NCT03819153). This new perspective offers the possibility to reduce the incidence of patients with moderatedadvanced stages of CKD as well as the need for RRT or kidney transplant, resulting in a decrease in hospitalizations and deaths due to renal causes and, consequently, a reduction in sanitary costs without sacrificing the quality of life of patients with CKD.

Author Contributions: Conceptualization: A.R.T., A.C.; literature search: A.R.T.; writing-original draft preparation, A.R.T.; writing-review and editing, A.C.; supervision: A.C. All authors have read and agreed to the published version of the manuscript.

Funding: This research received no external funding.

Institutional Review Board Statement: Not applicable.

Informed Consent Statement: Not applicable.

Data Availability Statement: Not applicable.

Conflicts of Interest: The authors declare no conflict of interest.

\section{References}

1. Muskiet, M.H.A.; Tonneijck, L.; Smits, M.M.; Kramer, M.H.H.; Heerspink, H.J.L.; van Raalte, D.H. Pleiotropic Effects of Type 2 Diabetes Management Strategies on Renal Risk Factors. Lancet Diabetes Endocrinol. 2015, 3, 367-381. [CrossRef]

2. Nathan, D.M. Diabetes: Advances in Diagnosis and Treatment. JAMA 2015, 314, 1052-1062. [CrossRef] [PubMed]

3. Gregg, E.W.; Li, Y.; Wang, J.; Rios Burrows, N.; Ali, M.K.; Rolka, D.; Williams, D.E.; Geiss, L. Changes in Diabetes-Related Complications in the United States, 1990-2010. N. Engl. J. Med. 2014, 370, 1514-1523. [CrossRef] [PubMed]

4. Gregg, E.W.; Sattar, N.; Ali, M.K. The Changing Face of Diabetes Complications. Lancet Diabetes Endocrinol. 2016, 4, 537-547. [CrossRef]

5. Thomas, M.C.; Cooper, M.E.; Zimmet, P. Changing Epidemiology of Type 2 Diabetes Mellitus and Associated Chronic Kidney Disease. Nat. Rev. Nephrol. 2016, 12, 73-81. [CrossRef] [PubMed]

6. Rodriguez-Poncelas, A.; Garre-Olmo, J.; Franch-Nadal, J.; Diez-Espino, J.; Mundet-Tuduri, X.; Barrot-De la Puente, J.; Coll-de Tuero, G.; RedGDPS Study Group. Prevalence of Chronic Kidney Disease in Patients with Type 2 Diabetes in Spain: PERCEDIME2 Study. BMC Nephrol. 2013, 14, 46. [CrossRef]

7. Bailey, R.A.; Wang, Y.; Zhu, V.; Rupnow, M.F.T. Chronic Kidney Disease in US Adults with Type 2 Diabetes: An Updated National Estimate of Prevalence Based on Kidney Disease: Improving Global Outcomes (KDIGO) Staging. BMC Res. Notes 2014, 7, 415. [CrossRef]

8. American Diabetes Association. 9. Pharmacologic Approaches to Glycemic Treatment: Standards of Medical Care in Diabetes2020. Diabetes Care 2020, 43 (Suppl. 1), S98-S110. [CrossRef] 
9. Zelniker, T.A.; Wiviott, S.D.; Raz, I.; Im, K.; Goodrich, E.L.; Furtado, R.H.M.; Bonaca, M.P.; Mosenzon, O.; Kato, E.T.; Cahn, A.; et al. Comparison of the Effects of Glucagon-Like Peptide Receptor Agonists and Sodium-Glucose Cotransporter 2 Inhibitors for Prevention of Major Adverse Cardiovascular and Renal Outcomes in Type 2 Diabetes Mellitus. Circulation 2019, 139, $2022-2031$. [CrossRef] [PubMed]

10. Muskiet, M.H.A.; Heerspink, H.J.L.; van Raalte, D.H. SGLT2 Inhibition: A New Era in Renoprotective Medicine? Lancet Diabetes Endocrinol. 2017, 5, 569-571. [CrossRef]

11. Yu, B.; Dong, C.; Hu, Z.; Liu, B. Effects of Sodium-Glucose Co-Transporter 2 (SGLT2) Inhibitors on Renal Outcomes in Patients with Type 2 Diabetes Mellitus and Chronic Kidney Disease. Medicine 2021, 100, e24655. [CrossRef] [PubMed]

12. Nauck, M.A.; Meier, J.J. The Incretin Effect in Healthy Individuals and Those with Type 2 Diabetes: Physiology, Pathophysiology, and Response to Therapeutic Interventions. Lancet Diabetes Endocrinol. 2016, 4, 525-536. [CrossRef]

13. Cho, Y.M.; Fujita, Y.; Kieffer, T.J. Glucagon-like Peptide-1: Glucose Homeostasis and Beyond. Annu. Rev. Physiol. 2014, 76, 535-559. [CrossRef] [PubMed]

14. Smits, M.M.; Tonneijck, L.; Muskiet, M.H.A.; Kramer, M.H.H.; Cahen, D.L.; van Raalte, D.H. Gastrointestinal Actions of Glucagon-like Peptide-1-Based Therapies: Glycaemic Control beyond the Pancreas. Diabetes Obes. Metab. 2016, 18, 224-235. [CrossRef] [PubMed]

15. Tahrani, A.A.; Barnett, A.H.; Bailey, C.J. Pharmacology and Therapeutic Implications of Current Drugs for Type 2 Diabetes Mellitus. Nat. Rev. Endocrinol. 2016, 12, 566-592. [CrossRef] [PubMed]

16. Meier, J.J. GLP-1 Receptor Agonists for Individualized Treatment of Type 2 Diabetes Mellitus. Nat. Rev. Endocrinol. 2012, 8 , 728-742. [CrossRef] [PubMed]

17. Jendle, J.; Nauck, M.A.; Matthews, D.R.; Frid, A.; Hermansen, K.; Düring, M.; Zdravkovic, M.; Strauss, B.J.; Garber, A.J.; LEAD-2 and LEAD-3 Study Groups. Weight Loss with Liraglutide, a Once-Daily Human Glucagon-like Peptide-1 Analogue for Type 2 Diabetes Treatment as Monotherapy or Added to Metformin, Is Primarily as a Result of a Reduction in Fat Tissue. Diabetes Obes. Metab. 2009, 11, 1163-1172. [CrossRef] [PubMed]

18. Wilding, J.P.H.; Batterham, R.L.; Calanna, S.; Davies, M.; Van Gaal, L.F.; Lingvay, I.; McGowan, B.M.; Rosenstock, J.; Tran, M.T.D.; Wadden, T.A.; et al. Once-Weekly Semaglutide in Adults with Overweight or Obesity. N. Engl. J. Med. 2021, 384, 989-1002. [CrossRef]

19. Marso, S.P.; Bain, S.C.; Consoli, A.; Eliaschewitz, F.G.; Jódar, E.; Leiter, L.A.; Lingvay, I.; Rosenstock, J.; Seufert, J.; Warren, M.L.; et al. Semaglutide and Cardiovascular Outcomes in Patients with Type 2 Diabetes. N. Engl. J. Med. 2016, 375, 1834-1844. [CrossRef]

20. Scheen, A.J. Pharmacokinetics and Clinical Use of Incretin-Based Therapies in Patients with Chronic Kidney Disease and Type 2 Diabetes. Clin. Pharm. 2015, 54, 1-21. [CrossRef]

21. Mann, J.F.E.; Hansen, T.; Idorn, T.; Leiter, L.A.; Marso, S.P.; Rossing, P.; Seufert, J.; Tadayon, S.; Vilsbøll, T. Effects of Once-Weekly Subcutaneous Semaglutide on Kidney Function and Safety in Patients with Type 2 Diabetes: A Post-Hoc Analysis of the SUSTAIN 1-7 Randomised Controlled Trials. Lancet Diabetes Endocrinol. 2020, 8, 880-893. [CrossRef]

22. Górriz, J.L.; Soler, M.J.; Navarro-González, J.F.; García-Carro, C.; Puchades, M.J.; D’Marco, L.; Martínez Castelao, A.; FernándezFernández, B.; Ortiz, A.; Górriz-Zambrano, C.; et al. GLP-1 Receptor Agonists and Diabetic Kidney Disease: A Call of Attention to Nephrologists. J. Clin. Med. 2020, 9, 947. [CrossRef]

23. Mann, J.F.E.; Fonseca, V.A.; Poulter, N.R.; Raz, I.; Idorn, T.; Rasmussen, S.; von Scholten, B.J.; Mosenzon, O.; LEADER Trial Investigators. Safety of Liraglutide in Type 2 Diabetes and Chronic Kidney Disease. Clin. J. Am. Soc. Nephrol. 2020, 15, 465-473. [CrossRef] [PubMed]

24. Nauck, M.A.; Homberger, E.; Siegel, E.G.; Allen, R.C.; Eaton, R.P.; Ebert, R.; Creutzfeldt, W. Incretin Effects of Increasing Glucose Loads in Man Calculated from Venous Insulin and C-Peptide Responses. J. Clin. Endocrinol. Metab. 1986, 63, 492-498. [CrossRef]

25. Michell, A.R.; Debnam, E.S.; Unwin, R.J. Regulation of Renal Function by the Gastrointestinal Tract: Potential Role of Gut-Derived Peptides and Hormones. Annu. Rev. Physiol. 2008, 70, 379-403. [CrossRef]

26. Thomas, L.; Kumar, R. Control of Renal Solute Excretion by Enteric Signals and Mediators. J. Am. Soc. Nephrol. 2008, 19, 207-212. [CrossRef]

27. Preston, R.A.; Afshartous, D.; Forte, L.R.; Rodco, R.; Alonso, A.B.; Garg, D.; Raij, L. Sodium Challenge Does Not Support an Acute Gastrointestinal-Renal Natriuretic Signaling Axis in Humans. Kidney Int. 2012, 82, 1313-1320. [CrossRef]

28. Singer, D.R.; Markandu, N.D.; Buckley, M.G.; Miller, M.A.; Sagnella, G.A.; MacGregor, G.A. Contrasting Endocrine Responses to Acute Oral Compared with Intravenous Sodium Loading in Normal Humans. Am. J. Physiol. 1998, 274, F111-F119. [CrossRef] [PubMed]

29. Hoorn, E.J.; Zietse, R. Gut-Kidney Kaliuretic Signaling: Looking Forward to Feeding. Kidney Int. 2015, 88, 1230-1232. [CrossRef] [PubMed]

30. Bankir, L.; Roussel, R.; Bouby, N. Protein- and Diabetes-Induced Glomerular Hyperfiltration: Role of Glucagon, Vasopressin, and Urea. Am. J. Physiol. Ren. Physiol. 2015, 309, F2-F23. [CrossRef] [PubMed]

31. Tonneijck, L.; Muskiet, M.H.A.; Smits, M.M.; van Bommel, E.J.; Heerspink, H.J.L.; van Raalte, D.H.; Joles, J.A. Glomerular Hyperfiltration in Diabetes: Mechanisms, Clinical Significance, and Treatment. J. Am. Soc. Nephrol. 2017, 28, 1023-1039. [CrossRef] [PubMed] 
32. Nauck, M. Incretin Therapies: Highlighting Common Features and Differences in the Modes of Action of Glucagon-like Peptide-1 Receptor Agonists and Dipeptidyl Peptidase-4 Inhibitors. Diabetes Obes. Metab. 2016, 18, 203-216. [CrossRef] [PubMed]

33. Bagger, J.I.; Knop, F.K.; Lund, A.; Vestergaard, H.; Holst, J.J.; Vilsbøll, T. Impaired Regulation of the Incretin Effect in Patients with Type 2 Diabetes. J. Clin. Endocrinol. Metab. 2011, 96, 737-745. [CrossRef] [PubMed]

34. van Bloemendaal, L.; Ten Kulve, J.S.; la Fleur, S.E.; Ijzerman, R.G.; Diamant, M. Effects of Glucagon-like Peptide 1 on Appetite and Body Weight: Focus on the CNS. J. Endocrinol. 2014, 221, T1-T16. [CrossRef] [PubMed]

35. Smits, M.M.; van Raalte, D.H.; Tonneijck, L.; Muskiet, M.H.A.; Kramer, M.H.H.; Cahen, D.L. GLP-1 Based Therapies: Clinical Implications for Gastroenterologists. Gut 2016, 65, 702-711. [CrossRef]

36. Muskiet, M.H.A.; Smits, M.M.; Morsink, L.M.; Diamant, M. The Gut-Renal Axis: Do Incretin-Based Agents Confer Renoprotection in Diabetes? Nat. Rev. Nephrol. 2014, 10, 88-103. [CrossRef]

37. Skov, J.; Dejgaard, A.; Frøkiær, J.; Holst, J.J.; Jonassen, T.; Rittig, S.; Christiansen, J.S. Glucagon-like Peptide-1 (GLP-1): Effect on Kidney Hemodynamics and Renin-Angiotensin-Aldosterone System in Healthy Men. J. Clin. Endocrinol. Metab. 2013, 98, E664-E671. [CrossRef]

38. Gutzwiller, J.-P.; Tschopp, S.; Bock, A.; Zehnder, C.E.; Huber, A.R.; Kreyenbuehl, M.; Gutmann, H.; Drewe, J.; Henzen, C.; Goeke, B.; et al. Glucagon-like Peptide 1 Induces Natriuresis in Healthy Subjects and in Insulin-Resistant Obese Men. J. Clin. Endocrinol. Metab. 2004, 89, 3055-3061. [CrossRef]

39. Kang, Z.; Zeng, J.; Zhang, T.; Lin, S.; Gao, J.; Jiang, C.; Fan, R.; Yin, D. Hyperglycemia Induces NF-KB Activation and MCP-1 Expression via Downregulating GLP-1R Expression in Rat Mesangial Cells: Inhibition by Metformin. Cell Biol. Int. 2019, 43, 940-953. [CrossRef]

40. Zhou, S.-J.; Bai, L.; Lv, L.; Chen, R.; Li, C.-J.; Liu, X.-Y.; Yu, D.-M.; Yu, P. Liraglutide Ameliorates Renal Injury in Streptozotocininduced Diabetic Rats by Activating Endothelial Nitric Oxide Synthase Activity via the Downregulation of the Nuclear Factor- $\mathrm{kB}$ Pathway. Mol. Med. Rep. 2014, 10, 2587-2594. [CrossRef]

41. Ye, Y.; Zhong, X.; Li, N.; Pan, T. Protective Effects of Liraglutide on Glomerular Podocytes in Obese Mice by Inhibiting the Inflammatory Factor TNF- $\alpha$-Mediated NF-KB and MAPK Pathway. Obes. Res. Clin. Pr. 2019, 13, 385-390. [CrossRef]

42. Wang, C.; Li, L.; Liu, S.; Liao, G.; Li, L.; Chen, Y.; Cheng, J.; Lu, Y.; Liu, J. GLP-1 Receptor Agonist Ameliorates Obesity-Induced Chronic Kidney Injury via Restoring Renal Metabolism Homeostasis. PLoS ONE 2018, 13, e0193473. [CrossRef]

43. Zitman-Gal, T.; Einbinder, Y.; Ohana, M.; Katzav, A.; Kartawy, A.; Benchetrit, S. Effect of Liraglutide on the Janus Kinase/Signal Transducer and Transcription Activator (JAK/STAT) Pathway in Diabetic Kidney Disease in Db/Db Mice and in Cultured Endothelial Cells. J. Diabetes 2019, 11, 656-664. [CrossRef] [PubMed]

44. Farah, L.X.S.; Valentini, V.; Pessoa, T.D.; Malnic, G.; McDonough, A.A.; Girardi, A.C.C. The Physiological Role of Glucagon-like Peptide-1 in the Regulation of Renal Function. Am. J. Physiol. Ren. Physiol. 2016, 310, F123-F127. [CrossRef] [PubMed]

45. Carraro-Lacroix, L.R.; Malnic, G.; Girardi, A.C.C. Regulation of Na+/H+ Exchanger NHE3 by Glucagon-like Peptide 1 Receptor Agonist Exendin-4 in Renal Proximal Tubule Cells. Am. J. Physiol. Ren. Physiol. 2009, 297, F1647-1655. [CrossRef] [PubMed]

46. Skov, J.; Pedersen, M.; Holst, J.J.; Madsen, B.; Goetze, J.P.; Rittig, S.; Jonassen, T.; Frøkiær, J.; Dejgaard, A.; Christiansen, J.S. Short-Term Effects of Liraglutide on Kidney Function and Vasoactive Hormones in Type 2 Diabetes: A Randomized Clinical Trial. Diabetes Obes. Metab. 2016, 18, 581-589. [CrossRef] [PubMed]

47. Asmar, A.; Simonsen, L.; Asmar, M.; Madsbad, S.; Holst, J.J.; Frandsen, E.; Moro, C.; Jonassen, T.; Bülow, J. Renal Extraction and Acute Effects of Glucagon-like Peptide-1 on Central and Renal Hemodynamics in Healthy Men. Am. J. Physiol. Endocrinol. Metab. 2015, 308, E641-E649. [CrossRef] [PubMed]

48. Zhou, X.; Huang, C.; Lao, J.; Pocai, A.; Forrest, G.; Price, O.; Roy, S.; Kelley, D.E.; Sullivan, K.A.; Forrest, M.J. Acute Hemodynamic and Renal Effects of Glucagon-like Peptide 1 Analog and Dipeptidyl Peptidase-4 Inhibitor in Rats. Cardiovasc. Diabetol. 2015, 14, 1-10. [CrossRef]

49. Moreno, C.; Mistry, M.; Roman, R.J. Renal Effects of Glucagon-like Peptide in Rats. Eur. J. Pharm. 2002, 434, 163-167. [CrossRef]

50. Sagoo, M.K.; Gnudi, L. Diabetic Nephropathy: An Overview. Methods Mol. Biol. 2020, 2067, 3-7. [CrossRef]

51. Han, F.; Hou, N.; Liu, Y.; Huang, N.; Pan, R.; Zhang, X.; Mao, E.; Sun, X. Liraglutide Improves Vascular Dysfunction by Regulating a CAMP-Independent PKA-AMPK Pathway in Perivascular Adipose Tissue in Obese Mice. Biomed. Pharm. 2019, 120, 109537. [CrossRef]

52. Sukumaran, V.; Tsuchimochi, H.; Sonobe, T.; Shirai, M.; Pearson, J.T. Liraglutide Improves Renal Endothelial Function in Obese Zucker Rats on a High-Salt Diet. J. Pharm. Exp. 2019, 369, 375-388. [CrossRef] [PubMed]

53. Jensen, E.P.; Poulsen, S.S.; Kissow, H.; Holstein-Rathlou, N.-H.; Deacon, C.F.; Jensen, B.L.; Holst, J.J.; Sorensen, C.M. Activation of GLP-1 Receptors on Vascular Smooth Muscle Cells Reduces the Autoregulatory Response in Afferent Arterioles and Increases Renal Blood Flow. Am. J. Physiol. Ren. Physiol. 2015, 308, F867-F877. [CrossRef] [PubMed]

54. Thomson, S.C.; Kashkouli, A.; Singh, P. Glucagon-like Peptide-1 Receptor Stimulation Increases GFR and Suppresses Proximal Reabsorption in the Rat. Am. J. Physiol. Ren. Physiol. 2013, 304, F137-F144. [CrossRef] [PubMed]

55. Muskiet, M.H.A.; Tonneijck, L.; Smits, M.M.; Kramer, M.H.H.; Diamant, M.; Joles, J.A.; van Raalte, D.H. Acute Renal Haemodynamic Effects of Glucagon-like Peptide-1 Receptor Agonist Exenatide in Healthy Overweight Men. Diabetes Obes. Metab. 2016, 18, 178-185. [CrossRef] 
56. Fujita, H.; Morii, T.; Fujishima, H.; Sato, T.; Shimizu, T.; Hosoba, M.; Tsukiyama, K.; Narita, T.; Takahashi, T.; Drucker, D.J.; et al. The Protective Roles of GLP-1R Signaling in Diabetic Nephropathy: Possible Mechanism and Therapeutic Potential. Kidney Int. 2014, 85, 579-589. [CrossRef]

57. von Scholten, B.J.; Lajer, M.; Goetze, J.P.; Persson, F.; Rossing, P. Time Course and Mechanisms of the Anti-Hypertensive and Renal Effects of Liraglutide Treatment. Diabet. Med. 2015, 32, 343-352. [CrossRef] [PubMed]

58. von Scholten, B.J.; Hansen, T.W.; Goetze, J.P.; Persson, F.; Rossing, P. Glucagon-like Peptide 1 Receptor Agonist (GLP-1 RA): Long-Term Effect on Kidney Function in Patients with Type 2 Diabetes. J. Diabetes Complicat. 2015, 29, 670-674. [CrossRef]

59. Lovshin, J.A.; Zinman, B. Blood Pressure-Lowering Effects of Incretin-Based Diabetes Therapies. Can. J. Diabetes 2014, 38, 364-371. [CrossRef] [PubMed]

60. Yang, J.; Jose, P.A.; Zeng, C. Gastrointestinal-Renal Axis: Role in the Regulation of Blood Pressure. J. Am. Heart Assoc. 2017, 6, e005536. [CrossRef]

61. Sun, F.; Wu, S.; Guo, S.; Yu, K.; Yang, Z.; Li, L.; Zhang, Y.; Quan, X.; Ji, L.; Zhan, S. Impact of GLP-1 Receptor Agonists on Blood Pressure, Heart Rate and Hypertension among Patients with Type 2 Diabetes: A Systematic Review and Network Meta-Analysis. Diabetes Res. Clin. Pr. 2015, 110, 26-37. [CrossRef] [PubMed]

62. Russo, G.; Piscitelli, P.; Giandalia, A.; Viazzi, F.; Pontremoli, R.; Fioretto, P.; De Cosmo, S. Atherogenic Dyslipidemia and Diabetic Nephropathy. J. Nephrol. 2020, 33, 1001-1008. [CrossRef] [PubMed]

63. Nyström, T.; Gutniak, M.K.; Zhang, Q.; Zhang, F.; Holst, J.J.; Ahrén, B.; Sjöholm, A. Effects of Glucagon-like Peptide-1 on Endothelial Function in Type 2 Diabetes Patients with Stable Coronary Artery Disease. Am. J. Physiol. Endocrinol. Metab. 2004, 287, E1209-E1215. [CrossRef] [PubMed]

64. Nyström, T.; Gonon, A.T.; Sjöholm, A.; Pernow, J. Glucagon-like Peptide-1 Relaxes Rat Conduit Arteries via an EndotheliumIndependent Mechanism. Regul. Pept. 2005, 125, 173-177. [CrossRef] [PubMed]

65. Muntner, P.; Coresh, J.; Smith, J.C.; Eckfeldt, J.; Klag, M.J. Plasma Lipids and Risk of Developing Renal Dysfunction: The Atherosclerosis Risk in Communities Study. Kidney Int. 2000, 58, 293-301. [CrossRef] [PubMed]

66. Sun, F.; Wu, S.; Wang, J.; Guo, S.; Chai, S.; Yang, Z.; Li, L.; Zhang, Y.; Ji, L.; Zhan, S. Effect of Glucagon-like Peptide-1 Receptor Agonists on Lipid Profiles among Type 2 Diabetes: A Systematic Review and Network Meta-Analysis. Clin. Ther. 2015, 37, 225-241. [CrossRef]

67. Jensen, M.D. Role of Body Fat Distribution and the Metabolic Complications of Obesity. J. Clin. Endocrinol. Metab. 2008, 93 (Suppl. 1), S57-S63. [CrossRef]

68. Thomson, S.C.; Vallon, V.; Blantz, R.C. Kidney Function in Early Diabetes: The Tubular Hypothesis of Glomerular Filtration. Am. J. Physiol. Ren. Physiol. 2004, 286, F8-F15. [CrossRef]

69. Hostetter, T.H. Hyperfiltration and Glomerulosclerosis. Semin. Nephrol. 2003, 23, 194-199. [CrossRef]

70. Leon, C.A.; Raij, L. Interaction of Haemodynamic and Metabolic Pathways in the Genesis of Diabetic Nephropathy. J. Hypertens. 2005, 23, 1931-1937. [CrossRef]

71. UK Prospective Diabetes Study (UKPDS) Group. Intensive Blood-Glucose Control with Sulphonylureas or Insulin Compared with Conventional Treatment and Risk of Complications in Patients with Type 2 Diabetes (UKPDS 33). Lancet 1998, 352, 837-853.

72. Foster, M.C.; Hwang, S.-J.; Larson, M.G.; Lichtman, J.H.; Parikh, N.I.; Vasan, R.S.; Levy, D.; Fox, C.S. Overweight, Obesity, and the Development of Stage 3 CKD: The Framingham Heart Study. Am. J. Kidney Dis. 2008, 52, 39-48. [CrossRef] [PubMed]

73. Hsu, C.; McCulloch, C.E.; Iribarren, C.; Darbinian, J.; Go, A.S. Body Mass Index and Risk for End-Stage Renal Disease. Ann. Intern. Med. 2006, 144, 21-28. [CrossRef]

74. Ejerblad, E.; Fored, C.M.; Lindblad, P.; Fryzek, J.; McLaughlin, J.K.; Nyrén, O. Obesity and Risk for Chronic Renal Failure. J. Am. Soc. Nephrol. 2006, 17, 1695-1702. [CrossRef] [PubMed]

75. Wang, Y.; Chen, X.; Song, Y.; Caballero, B.; Cheskin, L.J. Association between Obesity and Kidney Disease: A Systematic Review and Meta-Analysis. Kidney Int. 2008, 73, 19-33. [CrossRef] [PubMed]

76. Praga, M.; Morales, E. Obesity, Proteinuria and Progression of Renal Failure. Curr. Opin. Nephrol. Hypertens. 2006, 15, 481-486. [CrossRef]

77. Bunck, M.C.; Diamant, M.; Eliasson, B.; Cornér, A.; Shaginian, R.M.; Heine, R.J.; Taskinen, M.-R.; Yki-Järvinen, H.; Smith, U. Exenatide Affects Circulating Cardiovascular Risk Biomarkers Independently of Changes in Body Composition. Diabetes Care 2010, 33, 1734-1737. [CrossRef]

78. Buse, J.B.; Henry, R.R.; Han, J.; Kim, D.D.; Fineman, M.S.; Baron, A.D.; Exenatide-113 Clinical Study Group. Effects of Exenatide (Exendin-4) on Glycemic Control over 30 Weeks in Sulfonylurea-Treated Patients with Type 2 Diabetes. Diabetes Care 2004, 27, 2628-2635. [CrossRef]

79. van Can, J.; Sloth, B.; Jensen, C.B.; Flint, A.; Blaak, E.E.; Saris, W.H.M. Effects of the Once-Daily GLP-1 Analog Liraglutide on Gastric Emptying, Glycemic Parameters, Appetite and Energy Metabolism in Obese, Non-Diabetic Adults. Int. J. Obes. 2014, 38, 784-793. [CrossRef] [PubMed]

80. Mann, J.F.E.; Ørsted, D.D.; Brown-Frandsen, K.; Marso, S.P.; Poulter, N.R.; Rasmussen, S.; Tornøe, K.; Zinman, B.; Buse, J.B.; LEADER Steering Committee and Investigators. Liraglutide and Renal Outcomes in Type 2 Diabetes. N. Engl. J. Med. 2017, 377, 839-848. [CrossRef] 
81. Mann, J.F.E.; Fonseca, V.; Mosenzon, O.; Raz, I.; Goldman, B.; Idorn, T.; von Scholten, B.J.; Poulter, N.R. Effects of Liraglutide Versus Placebo on Cardiovascular Events in Patients With Type 2 Diabetes Mellitus and Chronic Kidney Disease. Circulation 2018, 138, 2908-2918. [CrossRef]

82. Mosenzon, O.; Blicher, T.M.; Rosenlund, S.; Eriksson, J.W.; Heller, S.; Hels, O.H.; Pratley, R.; Sathyapalan, T.; Desouza, C.; PIONEER 5 Investigators. Efficacy and Safety of Oral Semaglutide in Patients with Type 2 Diabetes and Moderate Renal Impairment (PIONEER 5): A Placebo-Controlled, Randomised, Phase 3a Trial. Lancet Diabetes Endocrinol. 2019, 7, 515-527. [CrossRef]

83. Husain, M.; Birkenfeld, A.L.; Donsmark, M.; Dungan, K.; Eliaschewitz, F.G.; Franco, D.R.; Jeppesen, O.K.; Lingvay, I.; Mosenzon, O.; Pedersen, S.D.; et al. Oral Semaglutide and Cardiovascular Outcomes in Patients with Type 2 Diabetes. N. Engl. J. Med. 2019, 381, 841-851. [CrossRef] [PubMed]

84. Novo Nordisk A/S. Effect of Semaglutide Versus Placebo on the Progression of Renal Impairment in Subjects With Type 2 Diabetes and Chronic Kidney Disease; Clinical trial registration NCT03819153. clinicaltrials.gov; 2021. Available online: https: / / clinicaltrials.gov/ct2/show / NCT03819153 (accessed on 25 August 2021).

85. Tuttle, K.R.; Lakshmanan, M.C.; Rayner, B.; Busch, R.S.; Zimmermann, A.G.; Woodward, D.B.; Botros, F.T. Dulaglutide versus Insulin Glargine in Patients with Type 2 Diabetes and Moderate-to-Severe Chronic Kidney Disease (AWARD-7): A Multicentre, Open-Label, Randomised Trial. Lancet Diabetes Endocrinol. 2018, 6, 605-617. [CrossRef]

86. Gerstein, H.C.; Colhoun, H.M.; Dagenais, G.R.; Diaz, R.; Lakshmanan, M.; Pais, P.; Probstfield, J.; Botros, F.T.; Riddle, M.C.; Rydén, L.; et al. Dulaglutide and Renal Outcomes in Type 2 Diabetes: An Exploratory Analysis of the REWIND Randomised, Placebo-Controlled Trial. Lancet 2019, 394, 131-138. [CrossRef]

87. Holman, R.R.; Bethel, M.A.; Mentz, R.J.; Thompson, V.P.; Lokhnygina, Y.; Buse, J.B.; Chan, J.C.; Choi, J.; Gustavson, S.M.; Iqbal, N.; et al. Effects of Once-Weekly Exenatide on Cardiovascular Outcomes in Type 2 Diabetes. N. Engl. J. Med. 2017, 377, 1228-1239. [CrossRef] [PubMed]

88. Muskiet, M.H.A.; Bunck, M.C.; Heine, R.J.; Cornér, A.; Yki-Järvinen, H.; Eliasson, B.; Joles, J.A.; Diamant, M.; Tonneijck, L.; van Raalte, D.H. Exenatide Twice-Daily Does Not Affect Renal Function or Albuminuria Compared to Titrated Insulin Glargine in Patients with Type 2 Diabetes Mellitus: A Post-Hoc Analysis of a 52-Week Randomised Trial. Diabetes Res. Clin. Pract. 2019, 153, 14-22. [CrossRef]

89. Hernandez, A.F.; Green, J.B.; Janmohamed, S.; D’Agostino, R.B.; Granger, C.B.; Jones, N.P.; Leiter, L.A.; Rosenberg, A.E.; Sigmon, K.N.; Somerville, M.C.; et al. Albiglutide and Cardiovascular Outcomes in Patients with Type 2 Diabetes and Cardiovascular Disease (Harmony Outcomes): A Double-Blind, Randomised Placebo-Controlled Trial. Lancet 2018, 392, 1519-1529. [CrossRef]

90. Pfeffer, M.A.; Claggett, B.; Diaz, R.; Dickstein, K.; Gerstein, H.C.; Køber, L.V.; Lawson, F.C.; Ping, L.; Wei, X.; Lewis, E.F.; et al. Lixisenatide in Patients with Type 2 Diabetes and Acute Coronary Syndrome. N. Engl. J. Med. 2015, 373, 2247-2257. [CrossRef] 